\title{
INFLUENCE OF HYDRIC BALANCE ON ENVIRONEMNTAL PHYTOINDICATION OF RUDERAL FRAGMENTS
}

\author{
Elizabeth dos Santos Rios \\ Instituto de Biologia/UERJ \\ Flávia Constantino Vitória \\ Escola Politécnica/UFRJ \\ Josimar Ribeiro de Almeida \\ Escola Politécnica/UFRJ e Instituto de Química/UERJ \\ Manoel Gonçalves Rodrigues \\ Observatório Urbano/OUERJ/UN-Habitat
}

\begin{abstract}
The aim of this present work is to verify the action of the hydric balance on phyto-sociological and physic-ecological factors in plant from ruderal fragment. It was determined the leaf number (NF), dry weight of leaves (PSF), foliar area (AF) and the weight of the total dry substance (PMSt). With the values of AF and PMST, the growth analysis parameters had been calculated. These phytoecological factors are: index of foliar area (IAF), reason of the foliar area (RAF), absolute growth rate (TCA), production of dry substance rate (TPMS), relative growth rate (TCR), assimilating net rate (TAL). Also the phyto-sociological factors had been calculated: relative density (DR), absolute frequency (FA), relative frequency (FR), relative domain (DoR), importance value index (IVI) and relative importance (IR).In accordance with the hydric balance analysis in the region (Vassouras, Rio de Janeiro, $43^{\circ} 07^{\prime \prime} \mathrm{N} / 22^{\circ} 08^{\prime} \mathrm{S}$ ), it was obser ved that the analyzed locality has a period of drought that corresponds from May to September, when the temperature raises. The period of hydric excess is observed from October to January and in April, and in December, the summer time. The total annual average of the precipitation and the average temperature for the locality are, respectively, $1264,7 \mathrm{~mm}$ and $25,6^{\circ} \mathrm{C}$. It has a hydr ic annual deficit of $30 \mathrm{~mm}$ and an excess of 372 $\mathrm{mm}$.A cause that modifies the use of the LBC (folíolo-pecíolo angle class) in natural conditions is the environmental factors, as temperature, hydric deficit and nutritional state of the plant. Low wf had modified some morphologic parameters in ruderal plants, including the size and the total number of leaves in blossom. The reference value $(r)$ was determined as $30 \mathrm{~mm}$, based on comments on the leaves tissue formation and on growth curves. It is verified that the duration of plastocrono $(\mathrm{p} / \mathrm{r})$ was 0,61 per day and the rate of the leaves appearance in the launching is $(\mathrm{r} / \mathrm{p})$ 0,83 per day, for hydric excess in the plants under 0,12 deficit met $p / r=0,89$ per day and $r / p=$ day.
\end{abstract}

Keywords: Hydric, Environmental Phytoindication, Ruderal

\section{INTRODUCTION}

Plants show diverse types of environmental adaptation (modulation and modification) and genetic (evolution), as the amount and the quality of the 
predominant radiation. The modulation adaptations occur quickly and they are temporary. When the original situation returns, the initial behavior is soon reacquired. Examples of photo-modulation are the movements of the leaves by which the exposition of the leaf surface to the radiation to which is displayed is increased and other photo-tropical fotonásticos and fototáticos movements, (FINCH - SAVAGE \& ELSTON, 1982).

The modifying answers adapt the plants to the average conditions of radiation, during the growth period. With this, the structural characteristics of the plants are remained. Plants adapted to the shade develop, in the chloroplasts, high concentrations of chlorophyll, and accessory pigments. exposed to strongest radiations develop an efficient axial system of water conduction. Leaves have some cell layers in mesophyll and cells with abundant chloroplasts. In consequence of the structural adaptations and the active metabolic processes, the adapted plants exposed to the intense light produce greater amount of dry substance. It contains a higher content of energy, and its fertility is bigger (frequency of budding, formation of seeds, incomes of fruits). In contrast, plants adapted to the tenuous light are distinguished by the reduced production of dry substance, efficient protein synthesis, low breath and water renewal. These characteristics enable them to grow in places of modest amounts of energy. (FINCH - SAVAGE \& ELSTON, 1982).

The evolution adaptations to the available radiation are based on genotypic changes. They determine the differences, sometimes very notable ones, which appear in the ecology of distribution of various species and eco-type of plants. The modulation, modification and evolution adaptations are not excluded mutually, but they overlap. Exact adjustments guarantee the biggest possible use of the available radiation. If the space occupied by a group of plants is densely filled, such as in the tropical forests, this is due to the fact that the light is completely being explored by varied forms and vegetal species, with genetic different light requirements, but they are perfectly capable of adapting. The secondary radiation effects (heat, influences on the hydric balance) affect all the adaptations to the intensity of the local light. (TURNER \& KRAGH, 1980; GARDNER ET AL, 1981, IDSO ET AL, 1981). 
The cellular elongation of vegetal organs in growth is regulated by the water availability in the ground. When environmental factors limit the foliar expansion, the processes directly related to light interception, temperature regulation, evapotranspiration - hydric balance and diffusion of Co2 are reached (FITTER \& HAY, 1981). The hydric balance is a method to calculate the water availability in the ground for vegetal communities. It counts the precipitation before the potential evapotranspiration, taking into consideration the capacity of water storage in the ground. This water availability is a more correlated ecological factor with the geographic distribution of the vegetal species than the precipitation. The ground, natural water reservoir for the vegetation has a storage capacity that once saturated allows the percolating of the exceeding water for the table sheet. The water entrance is represented by the precipitation, while the main exit is the evapotranspiration. The hydric balance counts the precipitation before the potential evapotranspiration, considering a definitive value of the capacity of water storage in the ground. This is the maximum amount of water usable for plants that can be stored in the root zone. The root storage capacity is a characteristic of the plant, independent of the ground type.

Evapotranspiration is the combined process of transpiration and evaporation that vegetation provides. The plant transpiration occurs through stomata and the cuticle of plants using water that its root system has absorbed throughout the soil profile explored.

The evaporation corresponds to loss of water deposited on the surface of the plant and water in the soil. Evaporation is a physical process while perspiration is a biological process. In the latter case come into play physiological processes that control water loss by plants, which operate concurrently with the weather. The evapotranspiration rate is directly proportional to the energy balance of the evaporating surface and the removal of water molecules with that surface. Factors affecting evapotranspiration are the same for a water surface. In addition it affects in the transpiration of the opening of stomata. The larger the surface opening of the stomata, the greater the water loss by transpiration. The opening of stomata is a complex mechanism, which varies with plant species, but generally follows the availability of soil water, solar radiation intensity, plant metabolism and 
concentration solar plant metabolism and $\mathrm{CO} 2$ concentration. The stomata remain open as long as soil water availability. As there will be water restriction, the stomata will decrease its opening and it can be closed completely. If the restriction of water gradually increases, the plant mobilizes mechanisms to reduce perspiration.

The aim of this present work is to verify the action of the hydric balance on phytosociological and physic-ecological factors in plant from ruderal fragment.

\section{MATERIALS AND METHODS}

The study area is about $6200 \mathrm{~m} 2$ and it is located in Vassouras, Rio de Janeiro. The city has its areas distributed in the mountain plateaus of Paraíba River middle basin, it altitude is around 600 meters and with longitude and latitude respectively, $43^{\circ} 07^{\prime} \mathrm{W}$ and $22^{\circ} 08^{\prime} \mathrm{S}$. Among the vegetation that composes the ruderal fragment, there is the presence of the Malvaceae, Sidastrum micranthum (St. Hil.) Fryxell, Sida rhombifolia L. Sida carpinifolia L. and Sida cordifolia L. An automatic weather station was set up whose system of data acquisition by sensors at specific periods stores the information collected on magnetic tapes, which are then analyzed by a micro-computing system. It results in a final record of average temperature and humidity, solar radiation, net radiation, precipitation, wind speed. These data are used to determine the values of potential evaporation. We consider the energy balance for a column that extends from the ground to a reference height above the vegetation, where observations are made. This process can be described by the expression: $\mathrm{Rn}-\mathrm{Lee}-\mathrm{H}-\mathrm{G}=\partial \mathrm{A} / \partial \mathrm{t}$. Where, $\mathrm{Rn}$ is net radiation (Watt $/ \mathrm{m} 2$ ) Le = latent heat of vaporization (Joule $/ \mathrm{kg}$ ), $E=$ flow of water vapor $(\mathrm{Kg} / \mathrm{m} 2 \mathrm{~s}), \mathrm{H}=$ sensible heat flow $(\mathrm{Watt} / \mathrm{m} 2), \mathrm{G}=$ soil heat flow (Watt/m2), $A=$ heat storage column (Joule/m2). The heat storage in the colony should be composed by terms representing the latent and sensible heat storage inside itself and the heat storage in the vegetation mass. The duration of storage, according to Thom (1977) is given by: 
$\partial \mathrm{A} / \partial \mathrm{t}=\int \mathrm{p} 0 \mathrm{Zr} \mathrm{cp}(\partial \mathrm{T} / \partial \mathrm{t})+\int \mathrm{dz} 0 \mathrm{Zr}(\mathrm{cp} \mathrm{p} / \mathrm{Y})($ and $\partial / \partial \mathrm{t})+\int \mathrm{dz} 0 \mathrm{Zr} \mathrm{pv} \mathrm{CVG}(\mathrm{v}$ $\partial T / \partial t) d z$ equation (1). The equation that describes the evaporation of a non saturated surface, according to the Penman - Monteith formulation (THOM \& OLIVER, 1977), is:

$\operatorname{LeE}=(\Delta \mathrm{R} p+\mathrm{CP}(\mathrm{es}-\mathrm{e}) / \mathrm{ra}) /(\Delta+\mathrm{Y}(1+\mathrm{rc} / \mathrm{ra}))$ equation (2)

The symbols of these equations represent: $\mathrm{p}=$ air density $(\mathrm{kg} / \mathrm{m} 3), \mathrm{pv}=$ vegetation density $(\mathrm{kg} / \mathrm{m} 3), \mathrm{Cp}=$ specific heat of air at constant pressure (Joules / ( $\mathrm{kg} \mathrm{K})$ ); cvg = specific heat vegetation (Joule / $(\mathrm{kg} \mathrm{K})) \mathrm{T}$ = air temperature (K), Tv = vegetation temperature $(K)$ and = saturation pressure of water vapor in the air (Newton/m2), and pressure = water vapor in the air (Newton / m2) $\Delta=$ des $/ \mathrm{dT}$ (Newton / m2 K)), R = energy available on the surface (Watt / $m 2$ ), $Y=$ constant psychometric (Newton / $(\mathrm{m} 2 \mathrm{~K})$ ) ; ra = aerodynamic resistance to water flow (s / m) and $\mathrm{rc}=$ surface resistance to heat flow $(\mathrm{s} / \mathrm{m})$

The available energy at the surface is used to maintain the flow of sensible heat and latent heat. When the surface is saturated, the resistance becomes $\mathrm{rc}$ - is null, and the flow of water vapor occurs from the surface at its maximum value for the existing conditions, known as potential evaporation.

The aerodynamic resistance to the flow of water vapor (latent heat flow), is described by the equation:

$\{\mathrm{ra}=\operatorname{Ln}((\mathrm{Zr}-\mathrm{d}) / \mathrm{Zo})-\Psi \mathrm{m}\}\{\operatorname{Ln}((\mathrm{Zr}-\mathrm{d}) / \mathrm{ZV})-\Psi \mathrm{v}\} / \mathrm{k} 2 \mathrm{u}$ equation (3)

where $\mathrm{Zr}=$ reference height where measurements are made $(\mathrm{m}), \mathrm{d}=$ displacement height of zero plane $(\mathrm{m})=$ Zo roughness length for momentum of vegetation $(m)=Z V$ roughness length of vegetation to the flow of vapor $(m), k=$ von Karman constant $=0.41$ (dimensionless); $\Psi_{\mathrm{m}}, \Psi_{\mathrm{V}}=$ corrections that must suffer the flows under the conditions of atmospheric stability in which they occur.

One of the criteria for establishing measures of atmospheric stability is supported in the definition of the length of time stability of Monin - Obukhov, $(L)$, whose 
expression is: $L=U . P$ T 3 CP / $\mathrm{kg}(0.07+\mathrm{H}$ LeE), where friction velocity u.a in $\mathrm{m} /$ $\mathrm{s}$, $\mathrm{T}$ the air temperature in $\mathrm{K}$ e $\mathrm{g}$ a gravity acceleration in $\mathrm{m} / \mathrm{s} 2$. The differential equation that expresses the variation of wind speed with respect to height above a plane covered by vegetation or not, is $\Phi M=(u$. $K(z-d)) \Phi M$ where $\Phi M$ is a dimensionless function of stability for momentum, which takes values $>1$ when the atmosphere is stable, $<1$ when is unstable and $e=1$ when it is neutral.

The integration of the equation $\partial u / \partial z$ is dependent on knowledge of the link between the function of stability and height z. ФM have been experimentally established for different stability conditions, expressions that relate the height $z$ and length stability of Monin - Obukhov. The equation that expresses this relationship to the unstable atmosphere is given by $\Phi M=\{1-16(Z-d) / L\}-1 / 4$. Assuming this relationship, the equation $\partial u / \partial z$ can be integrated between levels $(d+Z o)-Z r$, and its solution by assigning $x=\{1-16(Z o / L\}-1 / 4$ and $x=\{1-16$ $(Z r-d) / L\}-1 / 4$, results in the equation: $u=u$. / $k\{L n((Z r-d) / Z o)-\Psi M\}$, in which $\Psi \mathrm{M} 1 \mathrm{Ln}=\{(1+\mathrm{x} 2)(1+\mathrm{x}) 2 /(1+\mathrm{x} 02)(1+\mathrm{x}) 2\}-\arctan 2 \mathrm{x}+2 \operatorname{arc} \tan \mathrm{x}$. An analogous procedure with respect to the profiles of vapor pressure and temperature in their differential forms, assuming $\Phi M=\Phi v=\{1-16(Z-d) / L\}$ $1 / 2$, for an unstable atmosphere, and integrating between the levels $(d+Z V)$ and $Z r$ produces the integral function of stability, $\Psi_{\mathrm{V} 1} \operatorname{Ln}=2\{(1+\mathrm{x} 2) /(1+\mathrm{x} 02)\}$. For stable atmosphere these functions have the forms in equations: $\Psi \mathrm{M} 2=5$ ( $\mathrm{Z}-\mathrm{d}$ Zo) / $\mathrm{L}$ and $\Psi_{\mathrm{V} 2}=5$ (Z - d - ZV) / L, in which it is assumed, as Webb (1979), which $\Phi \mathrm{H}=\Phi \mathrm{V} 1=\Phi \mathrm{M} 2=(1+5(\mathrm{Z}-\mathrm{d}) / \mathrm{L})$ Of course the conditions of neutrality in the atmosphere correspond to $\Psi \mathrm{H}=\Psi \mathrm{V} 1=\Psi \mathrm{M} 2=0$.

The procedure for the determination of potential evaporation, suitable for a set of meteorological observations, must run in each iteration the following calculations: 1) a value for the stability length of Monin - Obukhov $L$ (in the first iteration $L=\infty$ ), 2nd ) stability functions $\Psi \mathrm{M} . \Psi_{\mathrm{V}}$ given by equations $\Psi \mathrm{M} 1$ and $\Psi_{V} 1$ or $\Psi \mathrm{M} 2$ and $\Psi_{\mathrm{V} 2}$ as stability conditions indicated by the last value of $L$ that is being used, 3 ) the friction velocity $u$ by the equation $U, 4)$ the aerodynamic resistance ra through the equation ra; 5 ) the potential evaporation from the equation LeE (where $r c=0$ ), 6) the sensible heat flow $\mathrm{H}$, as unfamiliar term in the equation $\mathrm{Rn}-\mathrm{LeE}-\mathrm{H}-\mathrm{G}=\partial \mathrm{a}$ / $\left.\partial t, 7^{\circ}\right)$ a new stability length $L$ with the use of the corresponding equation. 
Finally verify the corrections done by the variables $\mathrm{E}, \mathrm{u}$. , $\mathrm{H}$ e $\mathrm{L}$. If they are small the process is closed, otherwise a new iteration must be performed. Upon completion of the two iterations, lower limits are defined (Li Ls) and higher (Li Ls), among which is the solution sought. In subsequent iterations, aiming an acceleration of the process, the value assumed in the first $L$ no longer corresponds to the last value found in the seventh item, but the midpoint of the range $\mathrm{Li}-\mathrm{Ls}$, designated by Lo. Subsequently the determination to a new value for $L$, from Lo, it is possible to reduce the interval $\mathrm{Li}$ - Ls, making one of the limits assume the value of Lo now, in correspondence to the following situations: when the new value of $L$ $>$ Lo then $\mathrm{Li}=\mathrm{Lo}$, when $\mathrm{L}<\mathrm{Lo}$ then $\mathrm{Ls}=\mathrm{Lo}$, after this reduction the new center point is calculated, and other operations of the procedure are performed.

The rate of evaporation LeE, the sensible heat flow $\mathrm{H}$ and friction velocity determine a measure of weather conditions across the stability length of Monin Obukhov ( $\mathrm{L})$, given by the equation $\mathrm{V}=\mathrm{L}+3$ PCPT / $\mathrm{kg}(\mathrm{H}+0,07 \mathrm{~L}$ and $\mathrm{E})$. The LeE equation can be used for the calculation of potential evaporation assuming rc $=0$, however, the aerodynamic resistance would occur when evaporation reached its maximum rate would not be known because it is dependent on weather conditions, and these conditions are changed whenever some flow is changed. If taken for simplicity the equality $\mathrm{ra}=\mathrm{ran}$ (where Ran is the aerodynamic resistance to neutral conditions), in fact values are established for resistance and flows, independent of weather conditions that may occur, which no longer maintains compliance with stability length that results from. Definitely functional relationships between variables would be lost.

In a different route, and in correspondence to the method of determining the potential evaporation, air resistance, as well as the flow, is determined iteratively. It is a procedure in which each iteration provides a better agreement between the stability conditions created taking $r c=0$. The variables that depend on these conditions, culminating with values compatible among the flows, resistance and stability length. 
The sample of the vegetation consisted of examples that had flowers and fruits. The collected material was pressed and dried by conventional procedures and after identification it has been deposited in the Herbarium of the Universidade Federal Rural do Rio de Janeiro (RBR). In the laboratory we proceeded to separate and count the leaves. In each plot were randomly sampled 50 leaves for the estimation of leaf area (AF). The leaf coverage area was established through planimetragem (planimeter type A OTT. Gayern Kempten, model 311). We also weighed the total dry matter of leaves collected in each plot. Thus, we determined the number of leaves (NF), leaves dry weight (PSF), leaf area (AF) and the total dry weight matter (PMST). From the values obtained for leaf area and dry weight, we calculated the parameters of growth analysis.

These factors were called phytoecological and are: leaf area index (IAF), leaf area ratio (RAF), absolute growth rate (TCA), production rate of dry matter (TPMS), relative growth rate (TCR), net assimilation rate (TAL). In addition to these parameters phytosociological factors were also calculated: relative density (DR), absolute frequency $(F A)$, relative frequency $(F R)$, relative dominance (DoR), importance value index (IVI) and relative importance (RI). The equations adopted were: leaf area index (IAF), which expresses the leaf area (AF) per unit of soil constant (S) established based on the spacing and number of plants: $I A F=A F / S$. 0.5. The leaf area ratio (RAF) is related to leaf area (LA) with a total weight of the plant $(\mathrm{Pt}): \mathrm{RAF}=\mathrm{AF} / \mathrm{Pt}$. The absolute growth rate $(\mathrm{TCA})$, which expresses the plant growth by weight (Ptn - Ptn - 1) between two consecutive samples (Tn - Tn 1) where: $T C A=((P t n-P t n-1)) /(T n-T T N-1)) g$ day-1. The rate of dry matter production $($ TPMS $)$ calculated by TPMS $=(($ Ptn $-P$ tn-1) $) / \mathrm{S} .($ Tn - TTN-1) $)$ g. Dm2 day -1 .

The relative growth rate (RGR), which represents the increase in weight per unit weight at the beginning of the period, calculated per day. TCR $=((\operatorname{InPtn}-\operatorname{InPtn}-1 /$ $(T n-T n-1))$ gg-1. day -1 , where $\mathrm{In}=$ natural logarithm for a period of growth $(T n-$ $T n$ - 1). The net assimilation rate ( TAL) that represents the plant's ability to increase the weight in terms of surface area per day, in which $A S=((\operatorname{Ptn}-\operatorname{Ptn}-1)$ / (AFN - AFN - 1) (InAFn - InAFn - 1) ( Tn - Tn - 1)). g. dm-2. day -1 relative density (DR): $\mathrm{DR}=\mathrm{Ne} / \mathrm{Nt} .100(\%)$, where $\mathrm{Ne}$ is the number of individuals of a species 
found in samples and $\mathrm{Nt}$ is the total number of individuals sampled. The absolute frequency (FA): FA = NAE / Nat. $100(\%)$, where NAE is the number of samples that occurred a certain species and Nat is the total number of samples done. The relative frequency (RF): RF = SAF / FAT. 100 (\%), where FAE refers to the absolute frequency of a given species and FAT is the sum of the absolute frequencies of all species of the community. Relative dominance $=$ DoR MSe $=$ / MST. 100 (\%), where MSe refers to the dry weight of dry matter accumulated by the whole community.

The importance value index (IVI): IVI $=\mathrm{DR}+\mathrm{FR}+\mathrm{DoR}$, and the relative importance (IR): IR = Ivie / IVIt x 100 (\%), where IVI refers to the importance value index of a particular IVIt population and is the sum of the indices of importance value of all the community's population.

Samples were collected to determine the class of leaflet-petiole angle (LBC), the thickness of the leaf tissue, plastochron index (IP), the dry matter content, the length of the budding and the central leaflet, weight and leaf area and the number of leaves. The plastochron index (IP), time interval between the initiation of two successive leaves, and leaf plastochron index (IPF) were defined by Erickson \& Michelini (1957). The length of the leaf emerging at the apex is used as scale morphology, and plants have no plastochron age when the length of the sheet serial $n$ equals the reference value $(R)$. The IP and IPF were determined by the formulas: IP $=n+\log L n-\log R / \log L n-(\log L n+1), I P F=I P-a$. If $n$ the number of leaves is greater than the reference length $(R), L n$ the length of the sheet (which by definition is greater than or equal to $R$ ) $L n+1$ the length of the leaf $\mathrm{N}+1$, which by definition is less than $R$, and a the serial number of any leaf along the stem. Being IP a linear function of time, it is possible the following equation: IP $=\log L o-\log R / P+(r / P$. T $)$, where $P$ is the rate of elongation plastochron $(\log L n-\log L n+1), P / r$ is the duration of plastochron and $r / P$ is the rate of leaf appearance. 


\section{RESULTS AND DISCUSSION}

The study area has a medium texture soil, sandy clay and acid. The pasture fields correspond to the area originally covered by dense forests on the highlands and lowlands in the swampy lowlands. The region is crossed by the Santana river, which originally had shallow bed, and when rained the area flooded. This began to be modified by successive deforestation, river dredging and the development of pastures. The climate of Vassouras, according to the classification of Köppen, is Aw (tropical wet). By Holdrigde system, this location is in the area of tropical rainforest, tropical forest with deciduous and mesophytic with high proportion of evergreen species.

According to the analysis of water balance in the region (Table 5 and 6), it is observed that the location has a dry period that corresponds to the months from May to September, where it appears to occur much higher temperature than precipitation. The water surplus period is observed in the months January to April, and then from October to December period of the summer. The average total annual rainfall and average temperature for locality are, respectively, $1264.7 \mathrm{~mm}$ and $25.6^{\circ} \mathrm{C}$. There is an annual water deficit of $30 \mathrm{~mm}$ and a surplus of $372 \mathrm{~mm}$.

Photoindication plant samples were obtained from ruderal phytofragment from the area of study and analysis of phytosociological and physic-ecological factors was done by taking two periods based on water balance (water deficiency and exceedance), to verify this influence on the development of these plants (Tables 1 , 2, 3 and 4).

Table 1: Physic-ecological factors during water deficiency

\begin{tabular}{|l|l|l|l|l|l|}
\hline $\begin{array}{l}\text { Ruderal } \\
\text { Phytoindication }\end{array}$ & DR (\%) & FR (\%) & DoR (\%) & IVI & IR (\%) \\
\hline Sidastrum micranthum & 12.87 & 43.22 & 28.51 & 84.6 & 0.403 \\
\hline Sida rhombifolia & 2.95 & 3.76 & 8.43 & 15.14 & 0.072 \\
\hline Sida carpinifolia & 2.04 & 2.87 & 2.37 & 7.28 & 0.035 \\
\hline Sida cordifolia & 3.94 & 4.45 & 8.94 & 17.33 & 0.087 \\
\hline
\end{tabular}


Table 2: Physic-ecological factors during water exceedance

\begin{tabular}{|l|l|l|l|l|l|}
\hline $\begin{array}{l}\text { Ruderal } \\
\text { Phytoindication }\end{array}$ & DR (\%) & FR (\%) & DoR (\%) & IVI & IR (\%) \\
\hline Sidastrum micranthum & 15.26 & 47.91 & 77.62 & 140.79 & 0.539 \\
\hline Sida rhombifolia & 3.34 & 4.84 & 12.81 & 20.99 & 0.08 \\
\hline Sida carpinifolia & 6.57 & 3.65 & 5.57 & 15.79 & 0.06 \\
\hline Sida cordifolia & 9.58 & 5.31 & 10.63 & 25.52 & 0.098 \\
\hline
\end{tabular}

The meristematic organization of these ruderal stem has high mitotic activity characterized by organogenic active phase (HALLÉ ET AL., 1978). The leaf ontogeny of the ruderal studied can be separated into two distinct stages (Hallé et al., 1978): first, in which growth occurs by cell division, and second, by cell accommodation.

Table 3: Physic-ecological factors during water deficiency

\begin{tabular}{|l|l|l|l|l|l|l|}
\hline $\begin{array}{l}\text { Ruderal } \\
\text { Phytoindication }\end{array}$ & $\begin{array}{l}\text { IAF } \\
\mathbf{d m}^{2}\end{array}$ & $\begin{array}{l}\text { RAF } \\
\mathbf{d m}^{2} \cdot \mathbf{g}^{-} \\
1\end{array}$ & $\begin{array}{l}\text { TCA } \\
\text { g. day }\end{array}$ & $\begin{array}{l}\text { TPMS } \\
\mathbf{g} \cdot \mathbf{d m}^{2} \\
\text { day }\end{array}$ & $\begin{array}{l}\text { TCR } \\
\mathbf{g} \cdot \mathbf{g}^{-1} \\
\text { day }^{-1}\end{array}$ & $\begin{array}{l}\text { TAL } \\
\mathbf{g} \cdot \mathbf{d m}^{2} \\
\text { day }^{-1}\end{array}$ \\
\hline $\begin{array}{l}\text { Sidastrum } \\
\text { micranthum }\end{array}$ & 13.13 & 0.54 & 0.15 & 0.013 & 0.023 & 0.014 \\
\hline $\begin{array}{l}\text { Sida } \\
\text { rhombifolia }\end{array}$ & 8.71 & 1.07 & 0.05 & 0.004 & 0.021 & 0.017 \\
\hline $\begin{array}{l}\text { Sida } \\
\text { carpinifolia }\end{array}$ & 9.54 & 2.02 & 0.03 & 0.003 & 0.001 & 0.001 \\
\hline Sida cordifolia & 7.69 & 0.68 & 0.12 & 0.019 & 0.037 & 0.023 \\
\hline
\end{tabular}

The dry matter accumulation increased with leaf age. The leaf area depends mainly on the level of moisture in the soil at the time of its expansion. The area increased in all cases was larger and more significant in the period without water deficit. The leaf expansion showed exponential growth, markedly influenced by water stress, which limited its cell elongation. The leaves of these ruderal in the early days of growth are directly dependent on a supply of water and nutrients photosimilated. The rapid stretching for a short period of time requires a large supply of these components. 
This seems to explain the rapid senescence of leaves in previous release, which will act as a source of assimilated to the new.

Table 4: Physic-ecological factors during water exceedance

\begin{tabular}{|l|l|l|l|l|l|l|}
\hline $\begin{array}{l}\text { Ruderal } \\
\text { Phytoindication }\end{array}$ & $\begin{array}{l}\text { IAF } \\
\mathbf{d m}^{2}\end{array}$ & $\begin{array}{l}\text { RAF } \\
\mathbf{d m}^{2} \\
\mathbf{g}^{-1}\end{array}$ & $\begin{array}{l}\text { TCA } \\
\mathbf{g} \cdot \mathbf{d i a}^{-1}\end{array}$ & $\begin{array}{l}\text { TPMS } \\
\mathbf{g} \cdot \mathbf{d m}^{2} \cdot \\
\text { day }\end{array}$ & $\begin{array}{l}\text { TCR } \\
\mathbf{g} \cdot \mathbf{g}^{-1} \\
\mathbf{d a y}^{-1}\end{array}$ & $\begin{array}{l}\text { TAL } \\
\mathbf{g} \cdot \mathbf{d m}^{2} \\
\text { day }^{-1}\end{array}$ \\
\hline $\begin{array}{l}\text { Sidastrum } \\
\text { micranthum }\end{array}$ & 16.78 & 0.98 & 0.27 & 0.018 & 0.052 & 0.027 \\
\hline Sida rhombifolia & 9.12 & 1.83 & 0.07 & 0.006 & 0.039 & 0.057 \\
\hline Sida carpinifolia & 13.67 & 2.77 & 0.08 & 0.005 & 0.003 & 0.002 \\
\hline Sida cordifolia & 9.56 & 0.79 & 0.29 & 0.021 & 0.045 & 0.0 \\
\hline
\end{tabular}

A cause that changes the use of LBC in natural conditions is environmental factors such as temperature, drought and nutritional status of the plant. Lamoreaux et al. (1978) suggested that the IP can be used to test the effects of environmental stresses on plant growth. The low wf $\Psi$ morphological parameters changed in ruderal plants, including the size and the total number of sheets in sprouting. The reference value $(R)$ was determined as $30 \mathrm{~mm}$, based on observations of the formation of internal tissues of the leaf and its growth curve. It appears that the duration of the plastochron $(p / r)$ was 0.61 per day and the rate of leaf appearance at the launch $(r / p)$ of 0.83 day- 1 for water surplus in plants under water deficits found - se $p / r$ and $r=0.12$ per day and $r / p=0.89$ day -1 .

On the Table 5 presents the monthly average temperature $(09$, specific humidity of air $(\mathrm{g} / \mathrm{kg})$ saturation deficit $(\mathrm{g} / \mathrm{kg})$, wind speed $(\mathrm{m} / \mathrm{s})$, solar radiation $(\mathrm{W} / \mathrm{m} 2)$ and net radiation $(\mathrm{W} / \mathrm{m} 2)$, and the total precipitation $(\mathrm{mm})$. The total available energy is shown in Table 6, in $\mathrm{mm}$ water equivalent. These values are embedded in the variations of energy storage within the ruderal fragment, as explained in the plots equation $\partial \mathrm{A} / \partial \mathrm{t}$. In determining these plots was assumed that the temporal variations of temperature and pressure of water vapor, the phytofragment noted above represent the pattern of variation along the column that extends from the ground to the reference height $\mathrm{Zr}$ (THOM \& OLIVER , 1977). 
This consideration allows an immediate solution to the first two integrals of the equation $\partial \mathrm{A} / \partial \mathrm{t}$, with respect to the third integral of that equation, which represents the variation of the energy storage of the mass of vegetation. It was assumed that this term followed the pattern of variation in energy storage in the air in the form of sensible heat. With respect to the flow of heat into the ground, given the low levels of radiation reaching the ground (about $3 \%$ of the radiation that reaches the top of the phytofragment) its contribution was neglected. The fall in the net radiation for rainy days and chosen days and as a general rule throughout the observation period was counterbalanced by the flow of sensible heat, and by the negative rates of change in energy storage within the phytofragment.

The variation of the energy stored inside the ruderal fragment during the occurrence of rainfall is along with the sensible heat flow for this phytofragment, one of the mechanisms that compensate to reduce the contribution of net radiation, the composition of total energy available to evaporation (Table 6).

Table 5: Average monthly values of meteorological parameters.

\begin{tabular}{|l|l|l|l|l|l|l|}
\hline T o C & $\begin{array}{l}\text { Specific } \\
\text { Humidity } \\
(\mathbf{g} / \mathbf{K g})\end{array}$ & $\begin{array}{l}\text { Saturatio } \\
\mathbf{n} \text { Deficit } \\
\mathbf{( g / K g})\end{array}$ & $\begin{array}{l}\text { Wind } \\
\mathbf{s p e e d} \\
\mathbf{( m / s )}\end{array}$ & $\begin{array}{l}\text { Net } \\
\text { Radiatio } \\
\mathbf{n}\left(\mathbf{W} / \mathbf{m}^{2}\right)\end{array}$ & $\begin{array}{l}\text { Solar } \\
\text { Radiatio } \\
\mathbf{n}\left(\mathbf{W} / \mathbf{m}^{2}\right)\end{array}$ & $\begin{array}{l}\text { Precipit } \\
\text { ation } \\
(\mathbf{m m})\end{array}$ \\
\hline 26,9 & 16,6 & 5,6 & 1,3 & 124 & 203 & 156 \\
25,8 & 17,8 & 3,1 & 1,2 & 101 & 153 & 197 \\
26,3 & 17,7 & 4,6 & 1,2 & 101 & 163 & 78 \\
24,8 & 16,9 & 2,4 & 1,3 & 97 & 132 & 385 \\
24,7 & 16,6 & 2,2 & 1,3 & 110 & 161 & 321 \\
23,8 & 16,5 & 2,3 & 1,3 & 96 & 137 & 425 \\
24,8 & 16,7 & 2,7 & 1,4 & 108 & 167 & 228 \\
25,4 & 15,7 & 4,7 & 1,4 & 128 & 179 & 128 \\
25,4 & 16,9 & 4,5 & 1,4 & 125 & 171 & 157 \\
25,9 & 16,9 & 4,3 & 1,6 & 129 & 187 & 164 \\
25,8 & 16,7 & 4,6 & 1,3 & 127 & 187 & 134 \\
25,9 & 16,2 & 4,5 & 1,9 & 145 & 207 & 206 \\
\hline
\end{tabular}


Table 6. Monthly average rates of actual and potential evaporation

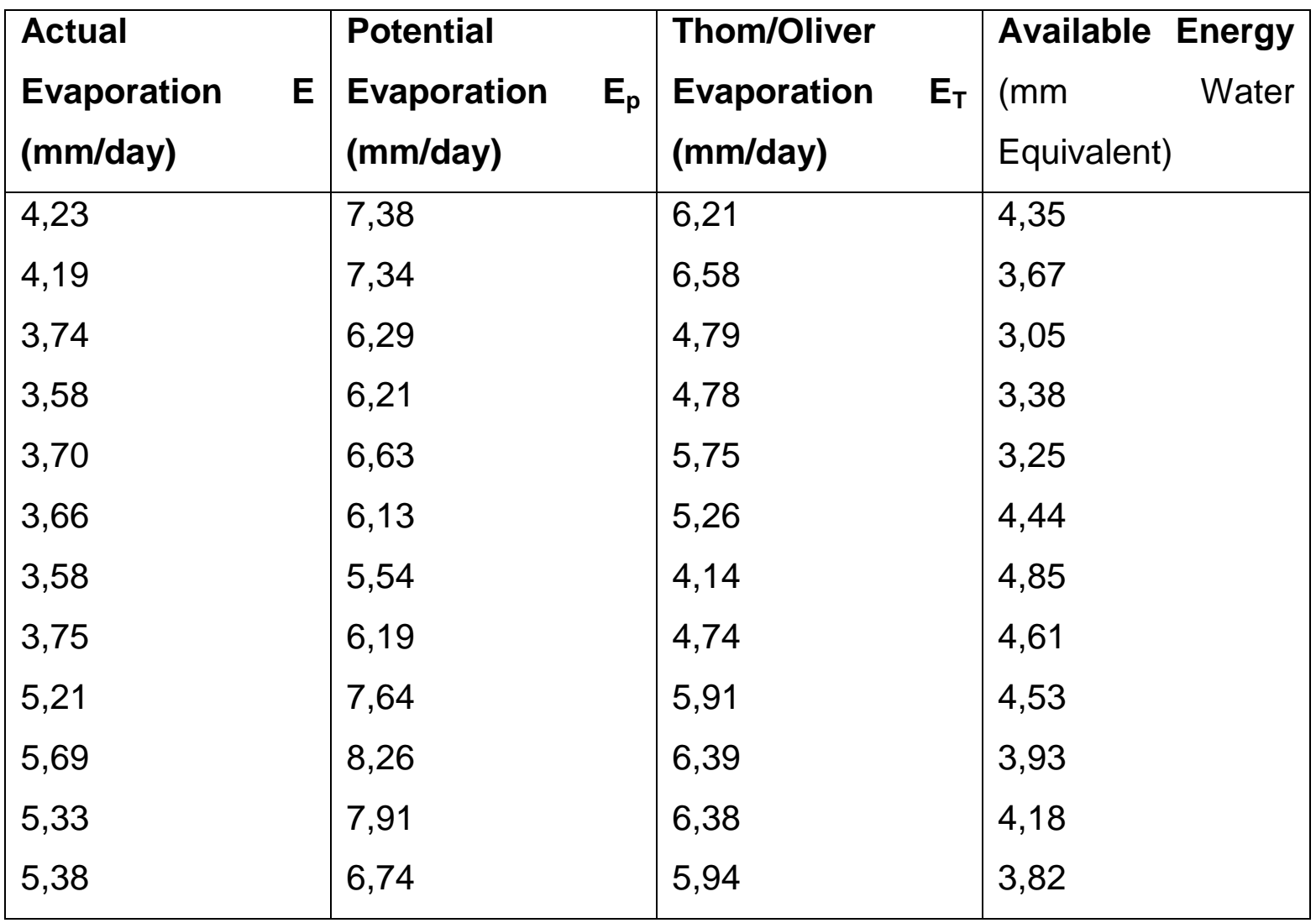

In the study area it was found that the ruderal plants adapt better to lands where surplus water occurs; the growth and development has increased in the summer.

\section{REFERENCES}

1. ERICKSON, R. O. \& MICHELINE, F. J. - 1957. The plastochron index. Amer. J. Bot., 44: 297 - 304.

2. FINCH-SAVAGE, W. E. \& ELSTON, J. 1982. The effect of temperature and water stress on the timing of leaf death in Vicia faba. Ann Appl, Biol., 100: 567 - 579

3. FITTER, A. H. \& HAY, R. K. M. - 1981. Environmental Physilogy of plants.London Academic Press. 355 p.

4. GARDNER, B. R.; BLAD, B. L. \& WATTS, D. G. Plant air temperature in differently irrigated corn. Agricultural Metodology, v 25, p 207 - 217, 1981.

5. HALLÊ, F.; OLDERMAN, R. A. A.; Tomlinson, P.b. - 1978. Tropical Trees and Forest, Berlim Springer - Verlag. 441 p. 
6. IDSO, S. B.; JOCKSON, R. D.; PINTER JUNIOR, P. J.; REGINATO, R. J. \& HATFIELD, J. C. Normaizing the stress degree day parameter for environmental variability. Agricultural Metodology, v 24, p 45-55, 1981.

7. LAMOREAUX, R. J. - 1978. The plastochorn index: review after two decades of use. Amer. J. Bot., 65: 586 - 593.

8. THOM, A. S. \& OLIVER, H. R. - 1977. On Penaman's equation for estimating regional evaporation. Quarterly Journal Royal Metereological Society, 103: 345 -357.

9. TURNER, N. C.; KRANGH, P. J. Adaptation of plants to water and high temperature stress. New York. John Wiley \& Sons, 1980. 428p.

10. WEBB, E. K. - 1979. Profile relationships: the log - linear range and extension to strong stability. Quarterly Journal Royal Metereological Society. 96:67-90 
